\title{
Effect of dextran on the reaction between rheumatoid factor and human gamma globulin
}

\author{
A. E. FINKELSTEIN, G. ISLER, AND I. ORESKES \\ From the Rheumatology Research Department, Fundación CIMAE (Centro de Investigaciones Médicas Albert \\ Einstein), Buenos Aires, Argentina, and the Mount Sinai School of Medicine of the City University of New York, \\ New York, N.Y. 10029, U.S.A.
}

The present study on the effect of polysaccharide dextran on the interaction of human gamma globulin (IgG) with rheumatoid factor (RF), was initiated by Finkelstein, Kwok, and Bayles (1960) after a clinical observation that intravenous infusion of a $6 \mathrm{~g}$. per cent. saline solution of dextran, 75,000 MW in patients with active rheumatoid arthritis induces marked exacerbation of disease activity. This disease activity was accompanied by an increase of intravascular erythrocyte aggregation as evidenced by stereomicroscopic observation of the blood flow in the vessels of the bulbar conjunctiva (Finkelstein, Kwok, Hall, and Bayles, 1961).

We have reported previously that dextran, when added to a rheumatoid serum, induces a precipitate which contains all RF activity (Finkelstein and others, 1960). It has also been shown that immunoglobulin can be eluted from red cell surfaces with solution of dextran. The protein eluted from red cells of patients with rheumatoid arthritis (RA) and other diseases were shown to contain antiIgG activity (Finkelstein and others, 1960; Finkelstein and others, 1961; Blodgett, Hill, Mayne, and Owen, 1963; Finkelstein, Woerner, Smith, Bayles, and Levine, 1963).

In the present paper it will be demonstrated that, in the presence of dextran, both the agglutination of IgG-coated latex particles by sera containing RF and the amount of IgG precipitates are increased. Evidence is presented which supports the concept that dextran blocks the autoinhibitory IgG activity present in the patient's own serum, as well as the inhibitory activity of the pooled human IgG present in test systems, with consequent enhancement of the immunological interactions.

\section{Material and methods}

Dextran of various molecular weights was obtained from Abbot Laboratories, Detroit, Mich. Unless otherwise specified, dextran of 75,000 MW was used, dissolved in water or saline (0.15 M NaCl). Aggregates of IgG were prepared by sodium sulphate precipitation according to the method of Christian (1958). The standard method of Singer and Plotz (1956) was employed for the latexfixation test (FIILP), and for the sensitized sheep cell test the method of Rose, Ragan, Pearce, and Lipman (1948) was used.

\section{Precipitin studies}

(1) Whole rheumatoid factor serum was diluted 1:8 with $6 \mathrm{~g}$ per cent. solution of dextran, and as a control the same serum was diluted 1:8 in saline, without dextran. To $0.2 \mathrm{ml}$. of the diluted serum was added increasing amounts of aggregated IgG and the mixture was brought to a final volume $0.6 \mathrm{ml}$. with saline. The tubes were allowed to stand at room temperature for $1 \mathrm{hr}$, and then at $4^{\circ} \mathrm{C}$. for $24 \mathrm{hrs}$. The resulting precipitates were washed twice with ice cold saline at $4^{\circ} \mathrm{C}$., and the supernatant fluid decanted after centrifugation at $1,400 \mathrm{G}$ for $15 \mathrm{~min}$. The precipitates were dissolved in $0 \cdot 1 \mathrm{~N} \mathrm{NaOH}$, and protein concentration measured by the method of Lowry, Rosebrough, Farr, and Randall (1951).

(2) In another type of precipitin experiment, $0.25 \mathrm{ml}$. of rheumatoid factor serum was mixed with constant amounts of dextran solution and increasing amounts of aggregated IgG. The tubes were all brought to a final volume of $6 \mathrm{ml}$. with phosphate buffer, $\mathrm{pH} 8.0$ and incubated for 7 days at $4^{\circ} \mathrm{C}$. The precipitates were washed three times with ice cold saline and analysed for nitrogen by the Micro Kjeldhal technique, and both supernatants and dissolved precipitates assayed for RF activity.

Immunoelectrophoresis in agar gel was done by the technique of Scheidegger (1955).

\section{INHIBITION EXPERIMENTS}

Euglobulin inhibition

Euglobulin from pooled non-rheumatoid normal serum was obtained by dialysis against dilute phosphate citrate buffer at pH 5.8 at $4^{\circ} \mathrm{C}$. for $48 \mathrm{hrs}$ (Ziff, 1957). The precipitate was washed with cold buffer at $\mathrm{pH} 5.8$ and redissolved with neutral buffer to original volume. The capacity of 
this material to inhibit the agglutination in the FIILP test by rheumatoid serum was determined by the technique of Hall, Mednis, and Bayles, (1958).

\section{Block titration procedure}

This technique employing human IgG coated tanned sheep cells (TSC) at six different concentrations, $0 \cdot 125$, $0.25,0.50,1 \cdot 0,1.5$, and 2.0 vol per cent., was performed according to the method of Oreskes and Plotz (1965) and Oreskes and Shore (1966). Equal volumes of test serum and $0.15 \mathrm{NaCl}$ of various concentrations of dextran or glucose were mixed and incubated at $37^{\circ} \mathrm{C}$. for $1 \mathrm{hr}$ before titration.

\section{Results}

In the following experiments the effect of dextran on agglutination, precipitation, and inhibition of agglutination in the rheumatoid factor-IgG immunoglobulin system have been studied.
Table I demonstrates that the presence of dextran enhances both the degree of agglutination and the titre of RF in the FIILP test procedure. To study further this phenomenon, equal volumes of various concentrations of dextran solution and RF serum were mixed and incubated at room temperature for 20 minutes. Precipitates were centrifuged and redissolved in glycine buffer, $\mathrm{pH} 8 \cdot 2$, and both supernatants and precipitate solutions tested for RF. As can be seen in Table II, more complete precipitation of rheumatoid factors was achieved with an aqueous solution of dextran. Identical results were obtained with the sensitized sheep cell test and the latex-fixation test in following the presence or absence of RF activity in precipitates or supernatants.

The experiment described in Table II was repeated with dextrans of MW 10,000, 15,000, 25,000, 188,000, and 226,000 . In all cases the degree of completeness

Table I Enhancing effect of dextran on rheumatoid factor

Agglutination titres obtained with IgG coated latex particles

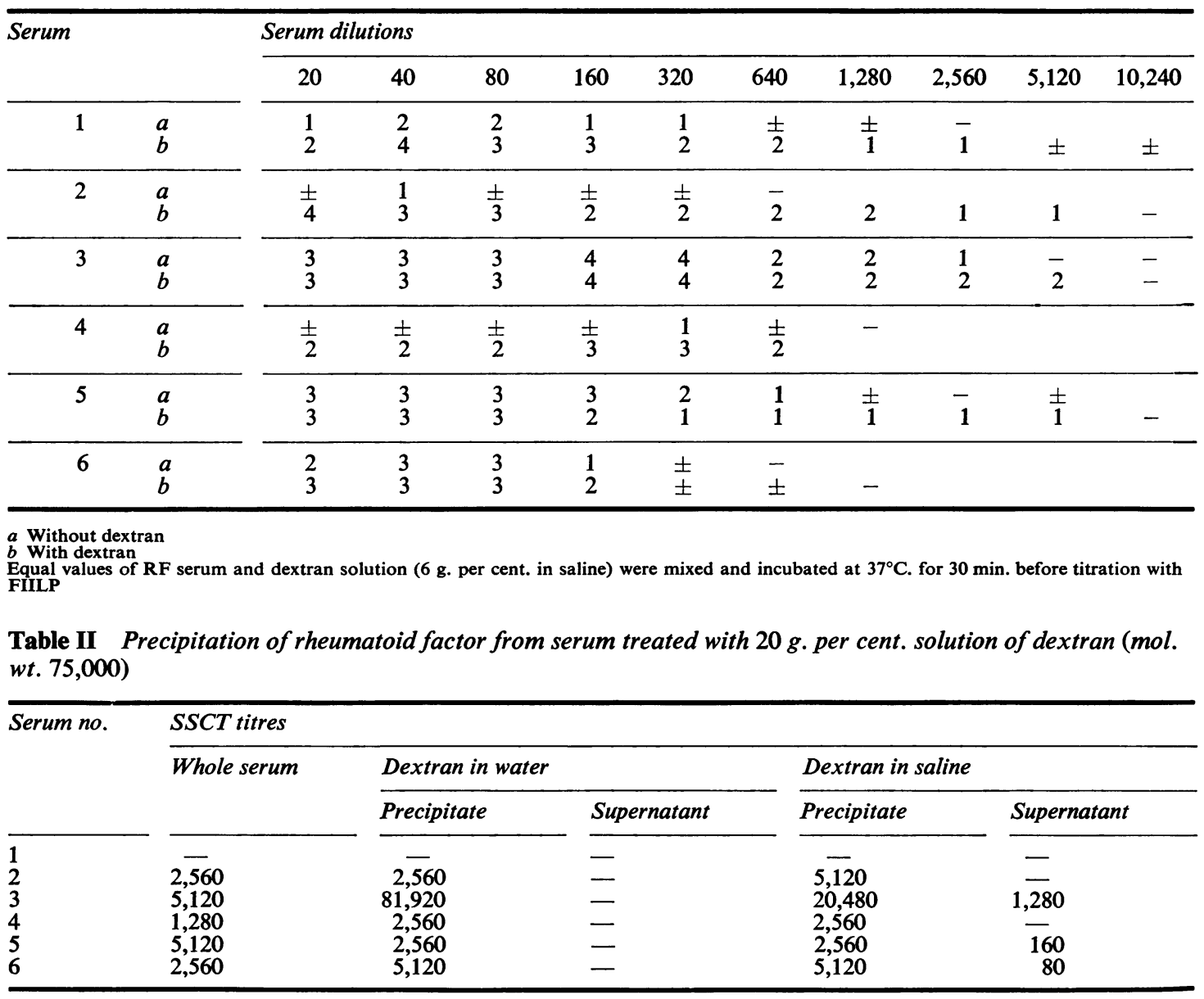


of RF precipitation was independent of molecular weight. Concentrations of 6,10 , and $15 \mathrm{~g}$. per cent. did not in all cases completely precipitate RF; a 20 per cent. concentration of dextran achieved RF free supernatants in all instances (Table III).

Table III Effect of concentration of dextran on precipitation of rheumatoid factor

\begin{tabular}{|c|c|c|}
\hline $\begin{array}{l}\text { Dextran } \\
\text { concentration } \\
\text { (g.per cent.) }\end{array}$ & & $\begin{array}{l}\text { Titre } \\
(S S C T)\end{array}$ \\
\hline 0 & Whole serum & 5,120 \\
\hline 6 & $\begin{array}{l}\text { Supernatant } \\
\text { Precipitate }\end{array}$ & $\begin{array}{r}40,960 \\
640\end{array}$ \\
\hline 10 & $\begin{array}{l}\text { Supernatant } \\
\text { Precipitate }\end{array}$ & $\begin{array}{r}20 \\
5,120\end{array}$ \\
\hline 20 & $\begin{array}{l}\text { Supernatant } \\
\text { Precipitate }\end{array}$ & $5 \overline{120}$ \\
\hline
\end{tabular}

With most sera addition of an equal volume of $6 \mathrm{~g}$. per cent. dextran yielded little or no precipitate. To determine the effect of 6 per cent dextran on the precipitin reaction between RF and aggregated IgG, the experiment shown in Fig. 1 was done. It can be seen that addition of dextran to constant RF serum and increments of aggregated IgG resulted in enhanced protein precipitation in every tube.

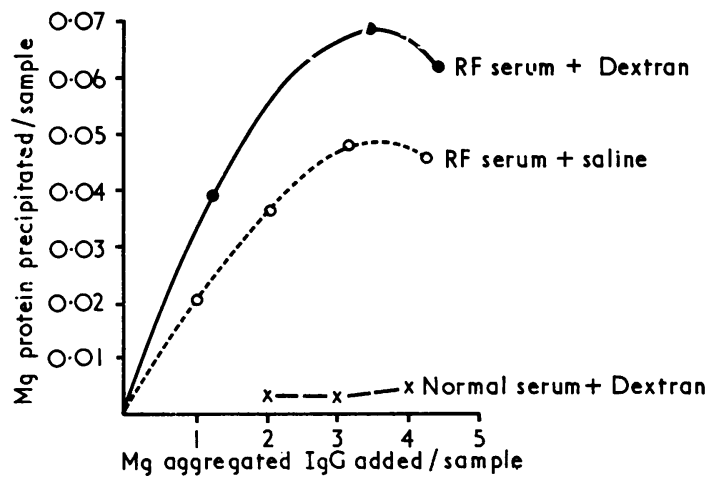

FIG. 1 Effect of dextran on the rheumatoid factoraggregates IgG interaction (Microprecipitation Method 1 in 'Material and Methods')

To study the RF content of supernatants, the above precipitin experiment was repeated in a larger volume. These data are shown in Fig. 2. It can be seen that in the absence of dextran, a typical RF precipitin curve was obtained with incomplete precipitation of RF even in the region of maximum protein precipitation. When dextran was added, two effects were noted: (1) The total amount of protein precipitation increased;

(2) Complete RF precipitation was achieved even at higher antigen concentrations.
It may be seen that dextran caused some precipitation of IgG in the absence of RF serum. When the RF saline precipitin curve was adjusted for presumed nonspecific precipitation of protein by dextran (dotted line), the curve obtained was still below the RF serum-dextran curve (Fig. 2).

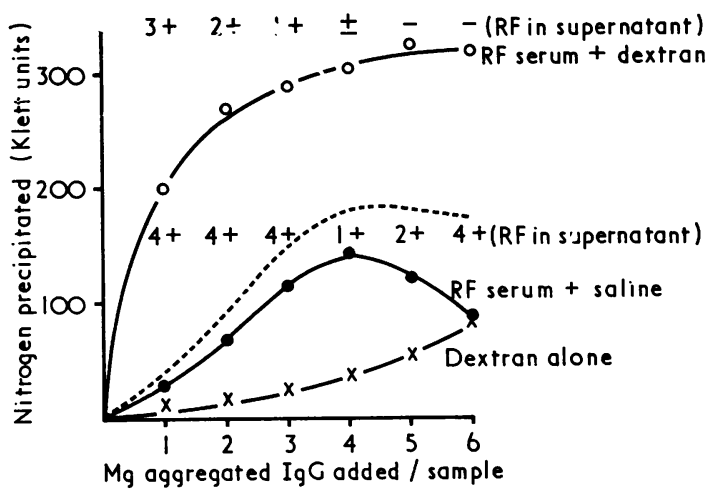

FIG. 2 Effect of dextran on rheumatoid factor-aggregate IgG interaction (Precipitation Method 2 in 'Material and Methods')

As previously noted, in most sera addition of a $6 \mathrm{~g}$. per cent. solution of dextran without added IgG did not yield precipitation. However, in one case, complete precipitation of RF activity did occur. Addition of dextran in concentrations up to $6 \mathrm{~g}$. per cent. to $\rightleftharpoons$ serum KJ (Fig. 3) induced a precipitate which increased linearly with dextran concentration between about $0 \cdot 1$ to $5.0 \mathrm{~g}$. per cent. dextran per ml. Serum $\mathrm{KJ}$ gave a prozone phenomenon with weak agglutination in the FIILP test and good agglutination in the SSCT. Addition of dextran to this serum abolished the prozone phenomenon and markedly enhanced the FIILP titre.

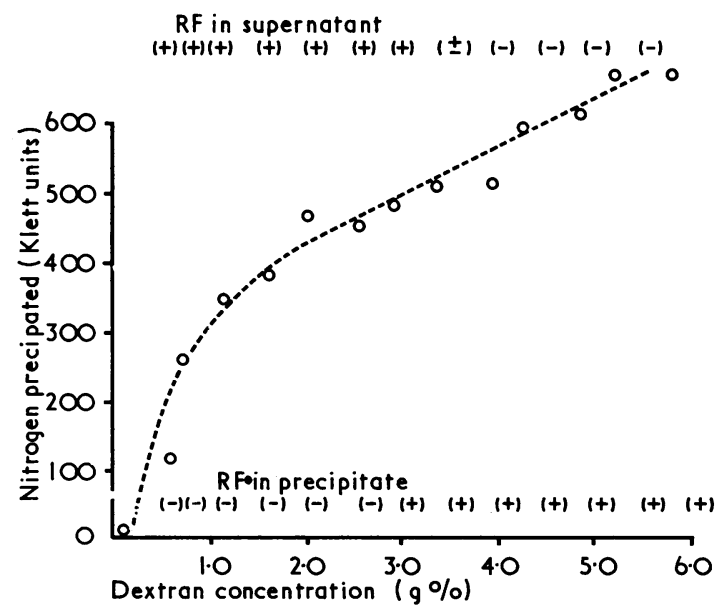

FIG. 3 Rheumatoid factor precipitation by dextran (Serum KJ) 
It has been established, then, that dextran enhances agglutination of FIILP by rheumatoid serum, and also enhances the precipitation of RF in precipitin studies. To test the possibility that dextran blocks the inhibitory effect of IgG upon rheumatoid activity, we studied the effect of dextran on inhibition of FIILP agglutination by the euglobulin fraction (Hall and others, 1958). Table IV shows that normal euglobulin fraction, treated with increasing amounts of dextran, progressively loses its capacity to inhibit agglutination of FIILP by a rheumatoid factor serum.

The blocking effect of dextran upon the autoinhibitory property of human serum IgG was further explored by a block titration procedure (Oreskes and Plotz, 1965; Oreskes and Shore, 1966).

Fig. 4 demonstrates the dependence of TSC titre for two RF sera on the concentration of IgG-coated tanned sheep cells employed. Titres were inversely proportional to cell concentration, and in general double logarithmic plots of titre as a function of cell concentration were linear. With one serum it may be seen that a twofold increase in cell concentration resulted in a two fold decrease in titre. This yielded a 'normal' slope value for the linear plot of $-1 \cdot 0$.

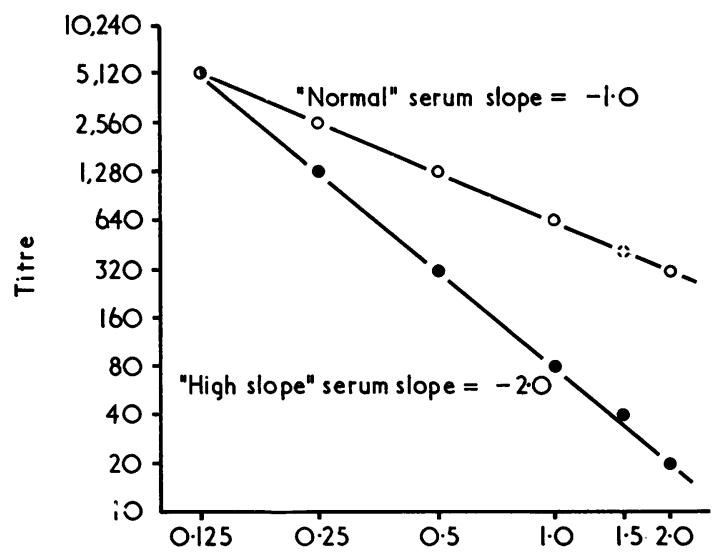

FIG. 4 Relationship between agglutination titres and concentrations of tanned coated cells in two RF sera
However, in the majority of RF sera tested, slope values of greater that -1.0 were obtained with values ranging up to $-2 \cdot 3$ (Oreskes and Plotz, 1965). In other words, most RF sera exhibited an enhanced decrease in titre with increasing cell concentration. An example of such a 'high slope' serum is shown in Fig. 4. Addition of heat-aggregated human IgG immunoglobulin to a normal slope serum resulted in an increase in slope as shown in Fig. 5. This increase in slope value demonstrated an inhibitory effect of the added aggregated IgG on titre (Oreskes and Plotz, 1965; Oreskes and Shore, 1966).

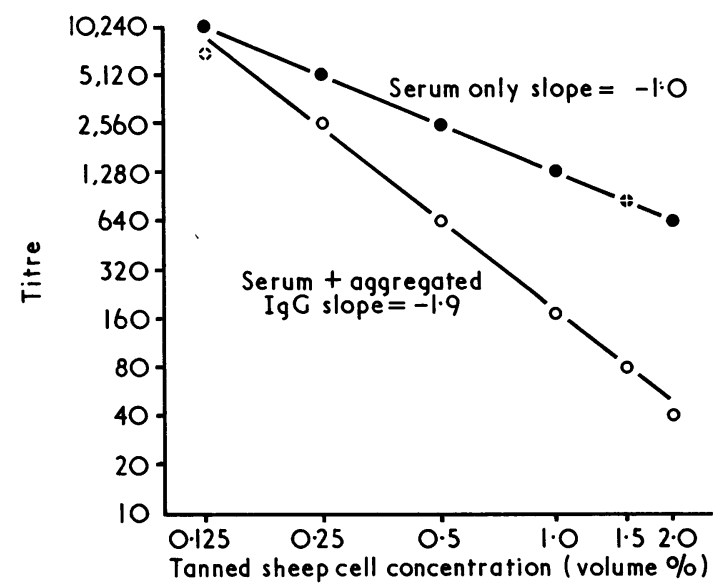

FIG. 5 Effect of aggregated human IgG immunoglobulin on agglutination titres and slope of RF serum. Aggregated $\gamma G: 10 \mathrm{mg}$. per cent. Solution of human $\gamma G$ immunoglobulin in $0.15 \mathrm{M} \mathrm{NaCl}$ heated at $63^{\circ} \mathrm{C}$. for $60 \mathrm{~min}$.; then $10 \mu \mathrm{l}$. $(0 \cdot 10$ $\mathrm{mg} \gamma \mathrm{G}$ ) added to $1.0 \mathrm{ml}$. test serum and incubated for $60 \mathrm{~min}$. at $37^{\circ} \mathrm{C}$. before titration

To test the effect of dextran on autoinhibition, this polysaccharide was added to a high slope serum (slope $=-1 \cdot 5)$. The results are shown in Fig. 6 .

In the presence of dextran, titres increased, particularly at higher tanned cell concentrations, and consequently the slope value was decreased, in this instance to a 'normal' value of $-1 \cdot 0$. Addition

Table IV Effect of dextran on euglobulin inhibition of IgG coated latex particle agglutination by rheumatoid factor serum

\begin{tabular}{|c|c|c|}
\hline \multicolumn{2}{|l|}{ Reaction mixture } & \multirow{2}{*}{$\frac{\text { Agglutination }}{3+}$} \\
\hline RF serum only & & \\
\hline RF serum + normal euglobulin & & - \\
\hline RF serum + normal euglobulin + dextran & $\begin{array}{l}0.1 \text { per cent. } \\
0.5 \text { per cent. } \\
1.0 \text { per cent. } \\
4.0 \text { per cent. } \\
8.0 \text { per cent. } \\
16.0 \text { per cent. } \\
20.0 \text { per cent. }\end{array}$ & $\begin{array}{l}\overline{1+} \\
2+ \\
3+ \\
3+ \\
4+ \\
4+\end{array}$ \\
\hline
\end{tabular}




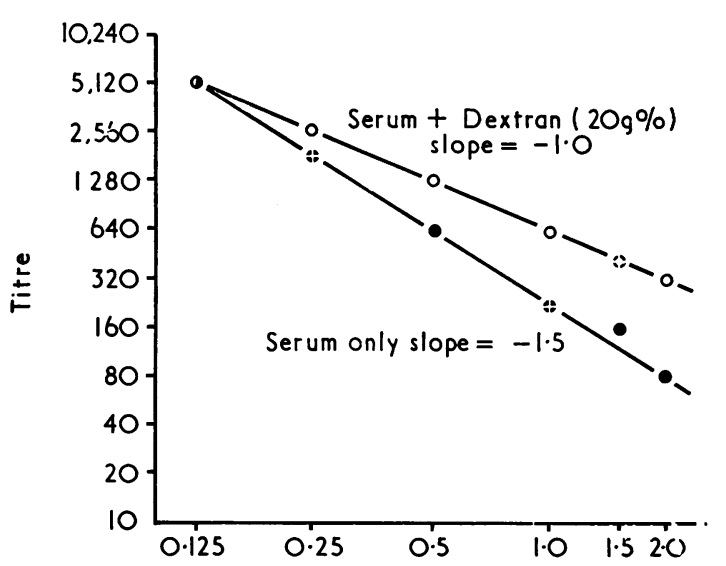

FIG. 6 Effects of dextran on agglutination titres and slope of a $R F$ serum

of dextran to a serum of 'normal' $-1 \cdot 0$ slope was without effect on the slope or on individual titres.

These effects are summarized in Table V. A RF serum when tested alone yielded a slope of $-1 \cdot 5$. Addition of dextran to this serum lowered the slope to -1.2. Addition of aggregated IgG in the absence of dextran raised the slope to $-1 \cdot 8$. Finally, addition of both dextran and aggregated IgG resulted in a lowered slope to a near 'normal' value of $-1 \cdot 1$. These results confirmed that the added dextran counteracted the inhibitory effects of autologous IgG as well as of added aggregated IgG.

The enhancing effect of dextran on agglutination titres and slopes was not a consequence of interactions between dextran and the IgG-coated tanned sheep cells used. Six different sera were titrated with tanned cells prepared as indicated (Oreskes and Plotz, 1965), and with cells additionally exposed to dextran before use. There was no difference in either agglutination titres or slopes obtained with the two types of cells.

In other experiments, addition to RF sera of $0 \cdot 15$ $\mathrm{M} \mathrm{NaCl}$ or glucose in varying concentrations up to $20 \mathrm{~g}$. per cent. was without effect on either titres or slopes.

Finally, Fig. 7 shows immunoelectrophoresis in agar gel of aliquots of IgG dissolved in saline (SIgG), and in a 2 per cent. solution of dextran (DIgG) against a rabbit antihuman IgG antisera. It can be seen that a larger thicker immunoprecipitin arch is elicited with the IgG dissolved in dextran as compared with the same amount of IgG dissolved in saline.

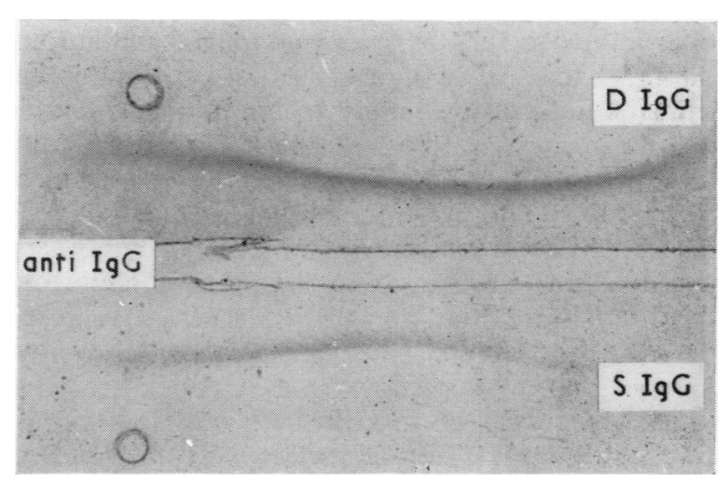

FIG. 7 Dextran enhancement of IgG precipitation by antilg $G$ antisera in immunoelectrophoresis

\section{Discussion}

In this study it has been demonstrated that solutions of dextran enhance the agglutination of latex particles coated with IgG by rheumatoid factor serum and enhance the precipitation of IgG-RF immune complexes. The effect obtained when dextran is added to euglobulin suggests binding of inhibitory IgG by this polysaccharide. Similarly, the presence of dextran diminishes the inhibitory capacity of autologous IgG present in the patient's serum, as evidenced by the slope lowering effect (Table V).

Dextran has also been shown to increase agglutination of antibodies in other immune systems. An antiA serum with an agglutination titre of 256 in saline solution showed a titre of 4,096 in medium containing $3 \mathrm{~g}$. per cent. dextran (Marston, 1954).

Although the work of Hellsing (1969a, b) points to the fact that dextran decreases the solubility of immune complexes because of steric exclusion, in the dextran IgG rheumatoid factor system both steric exclusion and a blockade of inhibitory IgG might be the mechanism for the enhancement of the RF-IgG interaction.

Table $\mathrm{V}$ Effect of dextran and aggregated IgG immunoglobulin on TSC titres and slopes of a rheumatoid factor serum

\section{System}

Serum alone

Serum + dextran $\dagger$

Serum + aggregated $\gamma \mathbf{G} \ddagger$

Serum + aggregated $\gamma \mathbf{G}+$ dextran

\section{TSC Titre*}

$1: 5120$

$1: 5120$

$1: 2560$

$1: 2560$

\begin{tabular}{l} 
Slope \\
\hline$-1 \cdot 5$ \\
$-1 \cdot 2$ \\
$-1 \cdot 8$ \\
$-1 \cdot 1$
\end{tabular}


For further discussion of the probable mechanisms of dextran participation in the immunological interactions, we refer the reader to Ceska's explanation of the effect of dextran upon insulin-antiinsulin precipitates (Ceska, 1968).

An important point arising from this work the question whether the blocking effect on autoinhibitory IgG by polysaccharides in rheumatoid arthritis induces increased precipitation of immune complexes in vivo, which play a role in the inflammatory reactions. This could be the mechanism of exacerbation of rheumatoid disease activity by dextran infusion described by Finkelstein and others, (1960). The adverse effect of intravenous irondextran in rheumatoid arthritis recently reported may be due to the same mechanism (Reddy and Lewis, 1969).

These observations together with work in progress, contraindicate infusion of solutions of dextran into patients with active rheumatoid disease, hypergammaglobulinaemia, and high rheumatoid factor titre, without simultaneous administration of steroids.

The data here presented are consistent with the concept that rheumatoid disease activity is mediated by IgG-RF immune complexes, and suggests that exacerbations of rheumatoid inflammation may be induced or enhanced by circulating polysaccharides.

\section{Summary}

Studies of the effect of dextran on the interaction of rheumatoid factor (RF) with human IgG have demonstrated that, in the presence of dextran, both the agglutination of IgG-coated latex particles by sera containing RF and the formation of immune precipitates are increased. Evidence is presented which supports the concept that the increment is due to the binding by dextran of inhibitory IgG present in the test system, and binding of autoinhibitory IgG in the patient's own serum. These data, plus earlier observations that in active rheumatoid arthritis infusion of dextran induces subjective and objective exacerbation of rheumatoid inflammation, suggest that rheumatoid inflammation is mediated by enhancement of intravascular immune precipitation by circulating polysaccharides of diverse origin.

We are indebted to Dr. Frank Gardner for his continuous interest and stimulus, to Drs. Arthur P. Hall and Ralph Heimer for their aid and advice, and to Dr. Theodore B. Bayles, Robert B. Brigham Hospital, Harvard Medical School, in whose laboratory this work was begun. We are grateful to Dr. Jose Zelasco, Head of the Department of Medicine, Fernández Hospital of Buenos Aires, for the clinical material, and to Dr. Leonor Martinez and Selva García, B.Sc., for assistance in some of the experimental work.

\section{References}

Blodgett, R. C., JR, Hill, R. W., Mayne, J. G., AND Owen, C. A. (1963) Arthr. and Rheum., 6, 264 (Similarities between an agglutinating factor eluted from erythrocytes of patients with rheumatoid arthritis and that found in acquired hemolytic anemia) (Abstract)

CESKA, M. (1968) Immunology, 15, 837 (Insulin anti-insulin precipitates in the presence of various dextrans)

Christian, C. L. (1958) J. exp. Med., 108, 139 (Characterization of the 'reactant'-gamma globulin factor-in the FII precipitin reaction and the FII tanned sheep cell agglutination test)

Finkelstein, A. E., KwoK, G., AND Bayles, T. B. (1960) Arthr. and Rheum., 3, 443 (Interaction of a polysaccharide with the rheumatoid factor from patient's serum and erythrocytes). (Abstract)

- - Hall, A. P., AND BAYLES, I. B. (1961) N. Engl.J. Med., 264, 270 (The erythrocyte in rheumatoid arthritis. I. A method for the detection of an abnormal globulin coating)

-, Woerner, T. E., Smith, J. C., Bayles, T. B., and Levine, N. D. (1963) Amer. J. Med., 35, 163 (abnormal globulins in myocardial infarction)

Hall, A. P., Mednis, A. D., ANd Bayles, T. B. (1958) N. Engl.J. Med., 258, 731 (The latex agglutination and inhibition reactions)

Hellsing, K. (1969a) Biochem. J., 112, 475 (Immune reactions in polysaccharide media)

- (1969b) Ibid., 114, 141 (Immune reactions in polysaccharide media. The composition of the antigen-antibody complexes in the precipitin reaction)

Lowry, O. H., Rosebrough, N. J., Farr, A., and Randall, R. J. (1951) J. biol. Chem., 193, 265 (Protein measurement with the folin phenol reagent)

MARSTON, N. A. (1954) Lancet, 2, 688 (Cross-matching of blood in the presence of dextran)

ORESKes, I., AND Plotz, C. M. (1965) J. Immunol., 94, 567 (Autoinhibition of rheumatoid factor reactivity demonstrated by a block hemagglutination procedure)

- AND SHORE, B. (1966) Ibid., 97, 600 (Dilution dependent autoinhibition of agglutination in rheumatoid arthritis sera and rabbit antihuman $\gamma \mathrm{G}$ antisera)

ReDdy, P. S., AND LeWIS, M. (1969) Arthr. and Rheum., 12, 454 (The adverse effect of intravenous iron-dextran in rheumatoid arthritis)

Rose, H. M., Ragan, C., Pearce, E., and Lipman, M. O. (1948) Proc. Soc. exp. Biol. (N. Y.), 68, 1 (Differential agglutination of normal and sensitized sheep erythrocytes of sera by patients with rheumatoid arthritis)

SCHEIDEgGer, J. J. (1955) Int. Arch. Allerg., 7, 103 (Une micro-methode de l'immunoelectrophorèse)

Singer J. M., AND Plotz C. M. (1956) Amer. J. Med., 21, 888 (Latex fixation text. I. Application to the serologic diagnosis of rheumatoid arthritis)

ZIFF, M. (1957) J. chron. Dis., 5, 644 (The agglutination reaction in rheumatoid arthritis) 